\title{
Britain Says NO: Voting in the AV Ballot Referendum
}

\author{
by \\ Paul Whiteley \\ Department of Government, University of Essex \\ email: whiteley@essex.ac.uk \\ Harold D. Clarke \\ Department of Political Science, University of Texas at Dallas \\ and Department of Government, University of Essex \\ email: clarke475@msn.com \\ David Sanders \\ Department of Government, University of Essex \\ email: sanders@essex.ac.uk \\ Marianne Stewart \\ Department of Political Science, University of Texas at Dallas \\ and Department of Government, University of Essex \\ email: mstewart@utdallas.edu
}

Version: EPOP 2011 


\begin{abstract}
The purpose of this paper is to explain why voters made the choices that they did in Britain's Alternative Vote referendum on May the $5^{\text {th }} 2011$. The paper utilises four alternative theoretical models to analyze individual voting behaviour. They are described as the cost-benefit, cognitive engagement, heuristics and mobilisation models. The explanatory power of these models is investigated using a large survey data set gathered in the AV Referendum Study conducted in conjunction with the British Election Study. Multivariate analyses show that all four models contribute to explaining why some people, but not others, voted in favour of electoral reform, with the cost-benefit model exhibiting particularly strong effects. The conclusion discusses public reactions to the referendum and possible implications of the decisive rejection of electoral reform.
\end{abstract}




\section{Britain Says NO: Voting in the AV Ballot Referendum}

The referendum on the Alternative Vote electoral system held on May $5^{\text {th }} 2011$ was the first nationwide referendum held in the UK since 1975 when the vote on continued membership of the European Community took place. The AV referendum arose out of the Coalition Agreement signed between the Conservatives and Liberal Democrats after the inconclusive general election of 2010. Negotiations on this issue were difficult because the Conservatives had opposed any change to the electoral system in their manifesto which promised to keep the first-past-the-post system (Conservative Party, 2010). In contrast, the Liberal Democrats called for a fully proportional electoral system in their manifesto (Liberal Democrats, 2010). In the end the two parties agreed a compromise, which was to hold a referendum on the Alternative Vote system, while acknowledging that they would campaign on opposite sides of the debate. It was a compromise which neither party really wanted, but which was reached in order to make the Coalition Agreement possible (Bogdanor, 2011; Norton, 2011).

The Parliamentary Voting Systems and Constituencies Bill introduced the legislation necessary to make the referendum possible. As the bill went through Parliament in October 2010, Caroline Lucas the newly elected Green Party MP for Brighton proposed an amendment which offered voters a choice of three different electoral systems in the referendum (Bogdanor, 2011: 94). But this was rejected and the deal agreed between the Conservatives and Liberal Democrats was preserved in the Bill. The referendum question read:

Do you want the United Kingdom to adopt the 'alternative vote' system instead of the current 'first past the post' system for electing Members of Parliament to the House of Commons?' After criticism by the Electoral Commission that this question was too difficult to understand, the wording was changed to read: 
'At present, the UK uses the 'first past the post' system to elect MPs to the House of Commons. Should the 'alternative vote' system be used instead?'

In the event, when the vote took place on May 5th, the referendum proposal was decisively rejected-32 per cent of the voters supported a change in the electoral system and 68 per cent opposed it, with a turnout of 42 per cent (Electoral Commission, 2011).

The purpose of this paper is to explain why voters made the choices that they did in the referendum. The paper utilises four alternative theoretical models to explain individual voting behaviour. We designate them as the 'cost-benefit', 'cognitive engagement', 'heuristics' and 'mobilisation' models, and they are described below. The models are tested using data from the AV Referendum Study conducted in conjunction with the British Election Study ${ }^{1}$ (BES). The paper begins with a theoretical discussion based on previous research, paying particular attention to explanations of why people vote in favour or against referendum propositions. The next section discusses the measurement of predictor variables specified in the four models. Then, we test the models using a multivariate analysis of referendum voting, and present data on public reactions to how the rival referendum campaigns were conducted. The conclusion discusses implications of the referendum for possible future reforms of the British political system.

\section{Theoretical Perspectives}

Referendums have been a topic of interest to political scientists for many years, and there are several overview volumes of research in the field (e.g., Butler and Ranney, 1994; Bowler and Donovan, 1998; Farrell and Schmitt-Beck, 2002; LeDuc, 2003; de Vrees, 2007). Alongside these collections are a number of case studies of particular referendums which have been held in different countries at different points of time (e.g., Clarke and Kornberg, 1994; Vowles, 1995; Blais et al., 1996; Marcussen and Zolner, 2001; LeDuc, 2005). One important topic considered is why referendums take place. The dominant explanation sees 
referendums as the product of an elite-level game conducted by rational actors, i.e., party strategists and leaders whose aim is to maximise their legislative representation (Boix, 1999; Benoit, 2004). Although interesting, these accounts tend to neglect the role of the voters who are treated largely as spectators in the elite-level contests.

However, it is not difficult to conceive of ways in which voters might get involved in such games as players who demand electoral or constitutional reforms. In a rational choice account voters will support a change in the political system if the benefits, as they see them, outweighed the costs of reform. Accordingly, the first of theoretical explanation we consider, the 'cost-benefit' model, takes such an approach to explaining why people voted to support or oppose the proposed change in the UK electoral system. Put simply, voters who opted to change to AV did so because they judged that the benefits of the new system outweighed its costs.

Rational choice accounts of the vote have been criticized because they make very strong assumptions about voters' cognitive capacities and decision-making abilities (e.g., Conlisk, 1996; Green and Shapiro, 1996). In this regard, a large number of survey respondents said that they did not understand the AV system and did not know how they were going to vote in the AV referendum. Regarding the latter, Figure 1A shows trends in vote intentions from January to early May 2011 using data from published public opinion polls and BES monthly surveys. In January about a third of the respondents said that they did not know if they supported or opposed a change in the electoral system. The size of the 'don't know' group declined over time but it was still running at about a fifth of the electorate two weeks before the balloting. This pattern is echoed in Figure 1B which displays data from the BES AV Referendum Study panel survey (described below) to track daily movements in support/opposition to AV in the month before the vote. This figure indicates that in early April between one-fifth and one-quarter of the respondents were uncertain about what they 
would do, and it was only in the last fortnight of the campaign that the number of 'don't knows' fell below 15 per cent as the number intending to vote No surged upward.

(Figure 1 about here)

Evidence concerning voters' levels of knowledge about the AV electoral system and politics more generally is also relevant. In this regard, a majority (51 per cent) of respondents in a BPIX survey conducted just over a week before the referendum said that they only partially understood AV or did not understand it at all ${ }^{2}$. Such ignorance or indifference should prompt abstention according to a rational choice explanation of participation (Downs, 1957; Whiteley, 1995). However, as Figure 2 documents, sizable minorities of people with very low levels of political knowledge nonetheless voted in support of a change in the electoral system ${ }^{3}$. Taken together, these survey data suggest that it is useful to consider other explanations of the vote in addition to a rational choice account.

(Figure 2 about here)

A second theoretical approach explains referendum voting with reference to people's cognitive engagement with politics (Norris, 2000; Clarke et al., 2004, 2009; Dalton, 2008). The cognitive engagement model claims that individuals participate if they have the ability and motivation to do so. Levels of knowledge and engagement with the political process are likely to be important factors in explaining involvement. Thus, if individuals are highly educated and knowledgeable they are likely to have the ability to participate in the sense of understanding how politics works and what it does to resolve societal conflicts. Equally, if people are interested in politics in general or in electoral reform in particular, then they are likely to have the motivation to vote in the referendum.

The cognitive engagement model has implications for how people voted in the referendum. Clearly, if individuals are not engaged with the debate over reform or do not understand the proposed system, then they are less likely to cast a ballot, although unlike in a 
rational choice account there is no presumption that they will always abstain. But, there is another effect at work too arising from the model. Evidence from a number of referendums in different countries suggests that there is a status quo bias, i.e., a tendency for people to vote against any change called for in a referendum (Nadeau, Martin and Blais, 1999; LeDuc, 2003; Clarke, Kornberg and Stewart, 2004) ${ }^{4}$. If people are not politically engaged and have little understanding of a proposed change, but nonetheless feel that they have a duty to vote, an easy solution to their choice problem is to support the status quo. This conjecture is consistent with research in experimental economics shows that individuals tend to be risk averse-weighing perceived costs more heavily than possible benefits when faced with a choice, the consequences of which are uncertain (e.g., Kahneman and Tversky, 1984; Thaler 1994). In the present context, the implication is that political engagement and knowledge should encourage individuals to vote Yes and disengagement should encourage the opposite response. So a prediction from the cognitive engagement model is that knowledgeable and engaged individuals will have a tendency to support a change to the electoral system and, accordingly, will vote in favour of AV.

The heuristics model complements the cognitive engagement model. In this case the idea is that when faced with uncertainty and complexity in decision-making, individuals use heuristics or 'rules of thumb' as cues which simply their choices. If a person is unsure of what to do in the referendum, an alternative strategy to just saying no would be to look for guidance from a trusted source such as a political party or a party leader (e.g., Popkin, 1991; Sniderman et al., 1991). For example, Conservative party identifiers and people with positive images of David Cameron might decide to vote No because of advice given by the Prime Minister or other senior Conservatives who have voiced their opposition to AV. The use of leader and partisan heuristics has been examined in analyses of electoral choice and their 
importance has been documented in numerous studies (e.g., Popkin, 1991; Sniderman et al., 1991; Lupia, 1994; Lupia and McCubbins, 1998; Clarke et al., 2004, 2009).

Such heuristics traditionally have been seen as imperfect alternatives to full information processing of the type which would take place if individuals had the time and resources to concentrate fully on the problem. In this view, the classical decision-making model is optimal and heuristics represent a deviation from this 'gold standard' (see, e.g., Keeney and Raiffa, 1993; Kuklinski and Quirk, 2000). However, recent research has shown that 'fast and frugal heuristics' can be as or more effective than full information processing in many real-world decision-making situations (Gigerenzer, 2008; see also Conlisk, 1996). This is because in reality decision-making is either too complex or too slow for effective choices to be made using classical utility maximization ${ }^{5}$. In the context of a national referendum campaign where political stakes are high and consequences of alternative outcomes are uncertain, it makes sense for voters to take advice from individuals and organisations they know and trust, such as political leaders and political parties.

The fourth theoretical perspective, the mobilisation model, captures the impact of campaigning on voting in the referendum. There is now an extensive literature showing that campaigning has a significant impact on turnout and party choice in general elections (e.g., Seyd and Whiteley, 1992; Pattie, Fieldhouse and Johnston, 1995; Green and Gerber, 2004). Similar to a general election, the AV referendum was characterized by considerable campaign activity. The pro-reform campaign operated under the rubric of the 'Yes to Fairer Votes' and the anti-reform campaign worked under the 'No to AV' banner. Both organizations sought to mobilize support from different political parties and interest groups as well as from various celebrities, media commentators, and opinion leaders. According to the mobilisation model, exposure to either of these rival campaigns should influence voters. 
To summarize, we expect people to be more likely to vote Yes in the AV referendum if they thought the benefits of change outweighed the costs. A similar expectation arises if they are knowledgeable and engaged both with politics in general and the referendum campaign in particular. Many people rely on partisan and leader heuristics to guide their political choices and, accordingly, party identifications and party leader images should have influenced referendum voting. Finally, contact by the Yes or the No campaigns should have affected how people voted. In the next section we discuss various predictor variables used to test these hypotheses.

\section{Measuring Predictor Variables}

The data used to test the models presented above were gathered in a two-wave panel survey that was the centrepiece of the British Election Study's AV Referendum Study. The first wave of the survey was carried out during the referendum campaign (from April 5th to May 4th 2011) and the second wave went into the field immediately after the vote. The survey was conducted on the internet, ${ }^{6}$ and it has a large number of cases (pre-referendum $\mathrm{N}$ $=22,124$, post-referendum $\mathrm{N}=18,556)$ to facilitate tracking the dynamics of public opinion in the run-up to the balloting ${ }^{7}$ and detailed investigation of forces affecting the behaviour of various groups. All predictor variables used in the present analyses, with the exception of the campaign contact and constitutional reform variables, were measured in the first (prereferendum) wave of the panel survey. Data on the dependent variable, voting yes or no in the referendum, were gathered in the second (post-referendum) wave. This measurement strategy helps to address possible simultaneity biases which can threaten the validity of statistical analyses, since it is unlikely that a variable measured after the referendum was over influenced one measured before it took place. ${ }^{8}$

Predictor variables in cost-benefit model are based on responses to a set of statements which probed opinions about the pros and cons of the alternative vote (AV) and first-past-the 
post (FPTP) electoral systems. These variables are direct measures of individual perceptions of the costs and benefits of electoral reform. There is also a battery of indicators tapping attitudes about wider constitutional reform issues which arose in the general election of 2010, and which could have influenced attitudes towards a change in the electoral system. Electoral reform was only one of several proposals for constitutional change discussed in the general election. Inter alia, these proposals include an elected House of Lords, reduction in the number of MPs in the House of Commons and devolution of powers from Whitehall to local governments. Opinions about these wider issues are probed to determine the extent to which preferences for electoral reform are driven, in part, by more general attitudes about the need for change in Britain's political system ${ }^{9}$.

\section{(Table 1 about here)}

Judgments about the possible costs and benefits of electoral reform as reflected in opinions about the advantages and disadvantages of the AV and FPTP electoral systems are displayed in Table $1^{10}$. These data show that the survey respondents are somewhat ambiguous about the advantages of $\mathrm{AV}$ with about 40 per cent believing that it is fairer and about the same proportion thinking the opposite. Similar ambiguity extends to the idea that AV gives too much influence to small parties and also to the argument that the results of AV elections more accurately represent public opinion. Interestingly, the only statement eliciting majority agreement (56 per cent) is that the first-past-the-post system enhances effective attribution of responsibility to political parties.

An exploratory factor analysis of these variables yielded a single factor which explains 58.1 per cent of the item variance. Factor scores from this analysis are used to measure opinion about the relative merits of the rival electoral systems. The several variables in the factor analysis are coded so that a high factor score indicates a favourable opinion 
towards AV in comparison with FPTP. Respondents with higher factor scores see relatively more benefits and fewer costs associated with a change in the electoral system.

Regarding constitutional change more generally, the manifestos of all three major parties gave considerable attention to this topic during the 2010 general election. This was largely a response to the widely publicized MPs' expenses scandal, which exercised press and public alike and drew attention to the issue of constitutional reform. The Liberal Democrats responded by calling for an elected House of Lords, a change to a proportional representation electoral system, more parliamentary scrutiny and a variety of other reforms (Liberal Democrats, 2010). The Conservatives' manifesto had a long section on the 'Big Society' which called for greater volunteering and the devolution of powers from Whitehall to local communities. Their manifesto also called for a reduction in the number of MPs to 600 and for the strengthening of civil liberties (Conservative Party, 2010). For its part, the Labour manifesto advocated fixed-term parliaments, strengthening of local government, and Lords reform (Labour Party, 2010). As a result, the AV referendum campaign occurred in a context in which constitutional reform had been on the agenda since the preceding general election a year earlier. With this in mind, we asked respondents a battery of questions about possible reforms to the British political system.

The responses (see Table 2) reveal widespread support for an elected House of Lords (61 per cent agreed), and a reduction in the number of MPs in the House of Commons to 600 (70 per cent agreed). There also was considerable agreement (58 percent) that local government should have more powers and strong opposition to the abolition of the monarchy (71 per cent disagreed). The idea of using referendums to decide important issues was popular as well, as was retention of the Church of England as a state church.

A factor analysis of these variables yielded two distinct factors which jointly explained 51.7 per cent of the item variance. The variables measuring opinion on an elected 
Lords, a smaller Commons, more powers to local government and more referendums to decide important issues loaded strongly on a factor which we label 'greater democracy' since a high score denotes support for all these reforms. Variables measuring opinions regarding the monarchy and Church of England load strongly on the second factor indicating, not surprisingly, that support for the monarchy is strongly associated with opposition to a change in the status of the church. We label this factor 'traditionalism"11. The expectation is that the democracy and traditionalism factors will have positive and negative impacts respectively, on the likelihood of casting a Yes ballot in the AV referendum.

(Table 2 about here)

Predictor variables in the cognitive engagement model include education, political knowledge, political interest and media consumption. Education and political knowledge are measures of people's ability to process information about politics and the extent to which they possess such information. Interest and media exposure gauge their willingness to try to understand it. The political knowledge scale introduced in Figure 2 above was constructed using a set of eight factual questions about British politics. Responses indicate that political knowledge is not especially high, since the mean score on the $0-8$ scale was 4.7 . This should be interpreted in the light of the fact that if individuals randomly guessed the answers to these true/false questions they would be expected to get a score of 4 by chance alone. Interest in the AV referendum and wider attention to politics in Britain were measured by 11-point scales ranging from 0 (low interest/attention) to 10 (high interest/attention).

Regarding media exposure, three questions asked respondents how much attention they paid to the referendum campaign in newspapers, on television and radio, and on the internet. Answers to these questions reveal that only small numbers of people monitored the campaign closely. Specifically, 8 per cent said that they paid a 'great deal' of attention to the campaign in newspapers; 10 per cent said this about television or radio, and 8 per cent, about 
the internet. Larger groups-ranging from 35 per cent for the internet to 39 per cent for newspapers to 49 per cent for TV and radio-indicated that they gave 'some' attention to the campaign. A media exposure variable was constructed by cumulating these responses into an overall index scored such that a high score indicates greater exposure to news about the referendum in the media and a low score indicates the opposite.

The heuristics model focuses on party leader images and partisanship. Leader images were measured via 11-point 'like'-'dislike' scales which provide excellent summaries of the impressions people have of political leaders (Clarke et al., 2009: ch. 5). If people trust a leader, think that he is strong, capable and listens to ordinary people then they will tend to like him, and these feelings play an important role in influencing their voting behaviour. Both Nick Clegg and Ed Miliband campaigned in favour of a change in the electoral system and David Cameron campaigned against it. Thus, liking Clegg or Miliband should encourage individuals to support electoral reform and liking Cameron should encourage them to oppose it. This said, Clegg's ability to convince large numbers of people to vote Yes was doubtful because his standing with the public had fallen sharply since before May 2010 election. Basking in the glow of 'Cleggmania' just before the general election, his average 'likeability' rating on a $0-10$ scale was a robust 5.6; a year later it had fallen nearly two full points to a very mediocre 3.7. Nor were Miliband or Cameron warmly received-in the run-up to the referendum their likeability scores were 4.2 and 4.4, respectively. Possible aggregate-level consequences of these ratings aside, Figure 3 illustrates that leader images have sizable and predictable individual-level correlations with the likelihood of voting Yes in the referendum.

(Figure 3 about here)

Turning to partisanship, the Liberal Democrats and the Conservatives took strong and opposing stands in the referendum campaign. However, Labour was in an ambiguous position since it was split on the issue. Although Labour Leader, Ed Miliband and a number 
of his shadow cabinet colleagues spoke in favour of $\mathrm{AV}$, prominent senior Labour politicians including Margaret Beckett, John Prescott and John Reid argued publicly to keep FPTP. This suggests that the partisan heuristic should work well for the Liberal Democrats and Conservatives, but not as well for Labour because the party was sending a mixed message. Empirically, this appears to be the case-among those casting a ballot, 80 per cent of Liberal Democrat identifiers voted Yes in the referendum and fully 88 per cent of Conservative identifiers voted No. However, Labour partisans were closely divided, with 46 per cent voting No and 54 per cent voting Yes.

The fourth model emphasizes the importance of mobilising voters by campaigning. A straightforward indicator is whether a respondent was contacted by the 'Yes to Fairer Votes' and the 'No to AV' campaigns. The data reveal that 22 per cent of the survey respondents were contacted by the former campaign, and 29 per cent were contacted by the latter one. Slightly less than one person in five (19 per cent) were contacted by both campaigns. Yes voting among those contacted by the Fairer Votes campaign only was eight per cent greater than among those contacted by the No to AV campaign only, and 15 per cent greater than among those who were not contacted by either campaign. Below, we investigate if this pattern persists in a multivariate model with controls for other possible influences on the vote.

In addition to the various indicators used to specify the four explanatory models, several socio-demographic variables were included as controls in the multivariate analysis. These variables were age, gender, and annual family income. In addition, dummy variables for residence in Scotland and Wales $^{12}$ were employed to proxy other possible factors affecting referendum voting in these countries. 


\section{Modelling Referendum Voting}

Parameters in the multivariate model of voting in the AV referendum were estimated using a binomial logit regression analysis, since the dependent variable was a dummy variable with Yes voters scored 1 and No voters scored zero (Borooah, 2002). As shown in Table 3, the scale measuring AV's perceived costs and benefits has a large, statistically significant, impact $(\mathrm{p}<.001)$ on the probability of casting a Yes vote. The democracy and traditionalism scales also have highly significant impacts $(\mathrm{p}<.001)$ and, as expected, opposite signs. Taken together, these results indicate that calculations of the costs and benefits of $\mathrm{AV}$ and more general attitudes towards constitutional change significantly influenced the vote. As hypothesized, people who judged that the AV system was an improvement over FPTP or who favoured wider constitutional reforms tended to vote 'Yes'. In contrast, those who preferred FPTP or were supporters of traditional British political institutions tended to vote 'No'.

(Table 3 about here)

Some of the variables associated with the cognitive engagement model also exercised significant effects on the probability of a Yes vote. Specifically the hypotheses that heightened interest in the campaign, greater knowledge of politics and higher levels of education enhance the likelihood of a Yes vote are confirmed $(\mathrm{p}<.001)$. These findings are consistent with the argument that disengaged, less well informed and poorly educated individuals who nonetheless decided to cast a ballot were likely to vote against change, thereby contributing to the status quo bias in the outcome.

Predictor variables associated with the heuristics and campaign contact models behave as expected as well. Thus, liking Cameron reduced the probability of voting in favour of electoral reform $(\mathrm{p}<.001)$, whereas liking Miliband or Clegg increased it $(\mathrm{p}<.001)$. Similarly, identification with the Conservative Party reduced the likelihood of a Yes vote, 
whereas identification with Labour or the Liberal Democrats increased it. Contact by the Yes to Fairer Votes organization significantly bolstered the probability of a Yes vote, whereas contact by No to AV reduced it.

Regarding other predictors, the data in Table 3 show that most socio-demographic characteristics were insignificant. There were two exceptions. One was gender, with men being more likely to vote Yes than women $(\mathrm{p}<.001)$. The other was residence in Scotland; with all other factors controlled, Scots were less likely to vote yes $(\mathrm{p}<.01)$ than were English (the country of residence reference category).

Since the binomial logit functional form is nonlinear, the substantive impact of statistically significant predictor variables is not readily apparent from the coefficients in Table 3. To provide intuition about the influence of various predictors, Figure 4 shows the effect on the probability of voting Yes of increasing a given predictor from its minimum to its maximum value while holding the other variables constant at their means. ${ }^{13}$ It is readily apparent that the cost-benefit scale has the largest impact on the Yes vote-changing this scale from its minimum to its maximum value increases the probability of voting yes by fully .99 points (on a $0-1$ probability scale). This huge shift reinforces the conjecture that perceptions of the (dis)advantages of a change in the system played a big part in explaining the results. The effects of the other two cost-benefit variables, the democracy and traditionalism scales, are considerably smaller (+.15 and -.28 points, respectively), albeit nontrivial.

(Figure 4 about here)

Regarding the cognitive engagement model, Figure 4 indicates that political knowledge played the largest role in influencing the Yes vote, closely followed by interest in the referendum campaign. Changes in the values of these two variables could change the probability of Yes vote by +.21 and +.09 points, respectively. As far as the heuristics model 
was concerned, increasingly positive views of Liberal Democrat Leader, Nick Clegg could increase the probability of a Yes vote by a substantial amount, +.32 points, whereas increasingly positive views of Conservative Leader, David Cameron, could decrease that probability by an equal amount. The effect of changing feelings about Ed Miliband was smaller, +.16 points. Party identification mattered as well, with Liberal Democratic identifiers being .15 points more likely than nonidentifiers (the party identification reference category) to support AV. The effect of Conservative identification was somewhat less, -.11 points, and, as expected, the effect of Labour identification was quite weak, -.05 points. Campaign effects were very modest, with contact by Yes to Fair Votes enhancing the probability of voting Yes by .05 points, and contact by No to Av lessening it by .03 points. Similarly small effects were associated with gender and country of residence; other things equal, men were .04 points more likely to vote Yes than were women. and residents of Scotland were -.04 points less likely to do so than were residents of England and Wales.

In summary, the multivariate analysis documents that all four models contribute to explaining why some people voted in favour of electoral reform, whereas others voted against it. The cost-benefit model stands out as highly influential. Evaluations of the advantages and disadvantages of a change in the electoral system had large effects on referendum voting decisions. Heuristics mattered too; consistent with earlier studies, leader images and partisanship had substantial effects on voting in the AV referendum. In addition, as expected, cognitively engaged people were more likely to opt for reform. Exposure to campaign contacting was influential as well, but the impact was quite modest. The overall explanatory power of the multivariate model is suggested by its very sizable McKelvey $R^{2}(.75)$, and its ability to correctly classify nearly 88 per cent of the voters correctly. 


\section{The Referendum in Retrospect}

One of the most obvious aspects of the AV referendum was the dismal turnout-only 42.2 percent of the electorate bothered to cast a ballot. Not only was this figure well off the already desultory level of participation (65.1 per cent) in the 2010 general election, it also was far below the 64.5 per cent turnout in the 1975 national referendum on Britain's continued membership in the European Community. The low turnout in the AV referendum suggests substantial public disengagement and disaffection. The rival campaigns clearly failed to mobilize a majority of the electorate and, as observed earlier, many people complained only a week before the balloting that they were not well-informed about what they were being called upon to decide.

In the wake of the referendum, public negativity about it was prevalent. When the BES post-referendum respondents were asked if there was a 'lot of mud-slinging' in the campaign, over three-fifths agreed and fewer than one in ten disagreed. Participants in the post-referendum survey also were presented with four positive words and four negative ones and asked to give their reactions to the Yes and No campaigns. Figure 5 documents that negative responses overshadowed positive ones by a substantial margin. The tenor of reactions was particularly evident for the Yes campaign, with only 5 per cent describing the campaign as strong and 34 per cent saying it was weak. Similarly, 13 per cent or less indicated the Yes effort was informative, positive and interesting, while 15 to 22 per cent said it was not informative, negative and boring. Overall, only 24 per cent designated one or more positive words to describe the Yes campaign and 53 per cent used one or more negative words. Reactions to the No campaign were only slightly more upbeat and, overall, 34 per cent made one or more positive remarks, and 44 per cent made one or more negative ones.

(Figure 5 about here) 
In retrospect, it is difficult to escape the conclusion that the AV referendum was a decidedly unsuccessful and unhelpful exercise in direct democracy. Despite repeated, if sometimes curious, efforts to inform people about the issues at stake in choosing an electoral system, ${ }^{14}$ the rival campaigns failed to inform and engage much of the electorate. A majority of people did not go to the polls and, as observed, many judged the competing campaigns negatively. This judgement reflected the harshly negative tenor of widely publicized attacks launched on each other by leading Yes and No advocates. ${ }^{15}$ Quite possibly, an important result is that the campaigns and the referendum outcome have contributed to growing sense that the British political system is seriously in need of reform. The latter outcome would be ironic; by conspicuously failing to achieve reform, the AV referendum may have heightened public appreciation of the need for it, while making it more difficult to achieve. We consider this possibility in the concluding section.

\section{Conclusion: The Consequences of a Decisive No}

The decisive outcome of the AV referendum has settled the issue and the question of electoral reform is unlikely to be re-opened for many years. If attempts are made to raise the issue again in the near future, opponents of reform will be able to say that the people have spoken and the question should no longer be up for discussion. Had the vote been closer, then supporters of a fully proportional electoral system might be able to argue that this should be on the agenda in coalition negotiations if a future general election proves as inconclusive as the last one. However, the strength of opposition to change in the electoral system manifest in the 2011 AV referendum makes this unlikely.

Another effect of the resounding rejection of electoral reform might be to inhibit attempts at other constitutional reforms such as an elected House of Lords and the devolution of power from Whitehall to local communities. If so, this is unfortunate because data presented above indicates there is substantial support for change. In addition, there is 
mounting evidence to suggest that the political institutions which generate support for British democracy are failing in comparison with an earlier era (Whiteley, 2011). Highly adverse public reactions to the MPs' expenses scandal and the recent News of the World phone hacking crimes are stark indicators of widespread discontent and lack of trust with the institutions and key actors in the contemporary British state. This negativity is unlikely to dissipate in the near future.

It can be argued that a loss of trust in key institutions such as Parliament and the Executive may encourage further use of referendums in the future. When institutions and elite actors are no longer trusted, referendums might serve to provide the legitimacy needed for major decisions. However, although BES survey evidence suggests there is substantial public support in the abstract for using referendums to decide important questions, the status quo bias discussed above is likely to be strong if people do not understand or are not engaged with the particular topic at issue. This tendency will be strengthened if they do not trust political leaders and political parties to give them guidance. There is a paradox that referendums are often called to settle constitutional questions that divide political parties, but almost by definition such issues are more likely to be seen as complicated and irrelevant to the lives of ordinary people in comparison with 'bread-and-butter' issues such as the economy and crime. It required more than a generation for a nationwide referendum to occur after the 1975 vote on continued British membership in the European Community. It is possible that the same thing may happen again. 
Figure 1A. Referendum Vote Intentions, January 2011 - May 2011

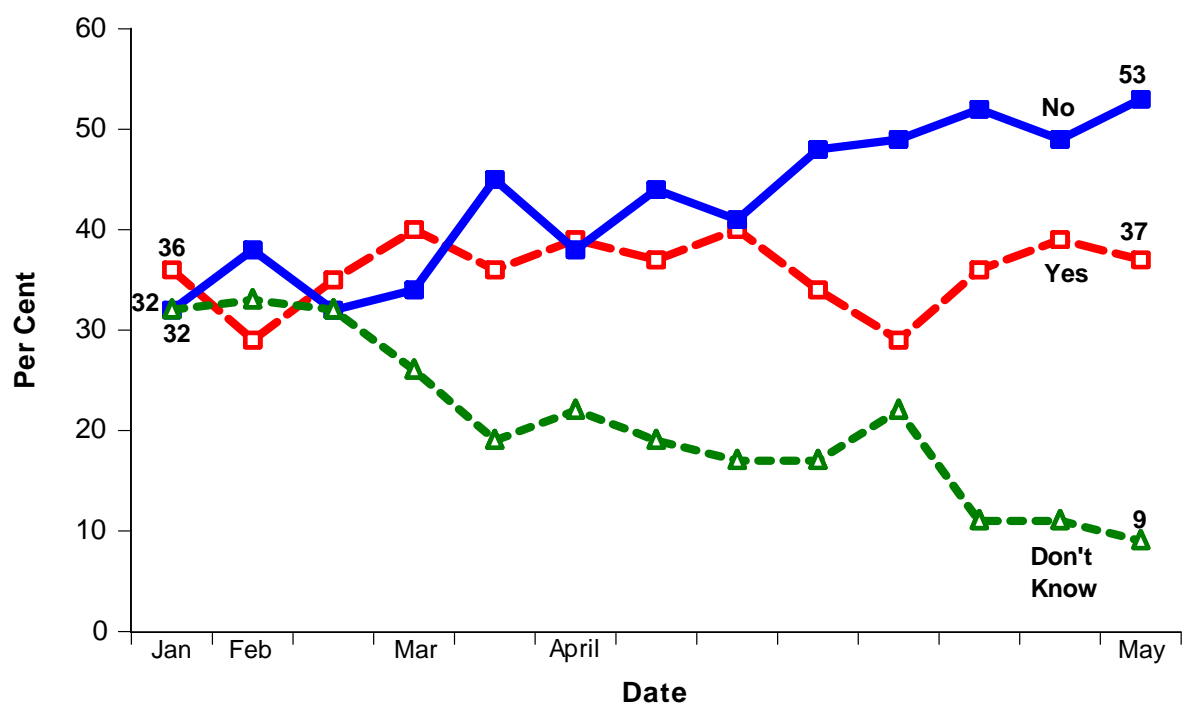

Figure 1B. Referendum Vote Intentions, April 5th-May 4th, 2011

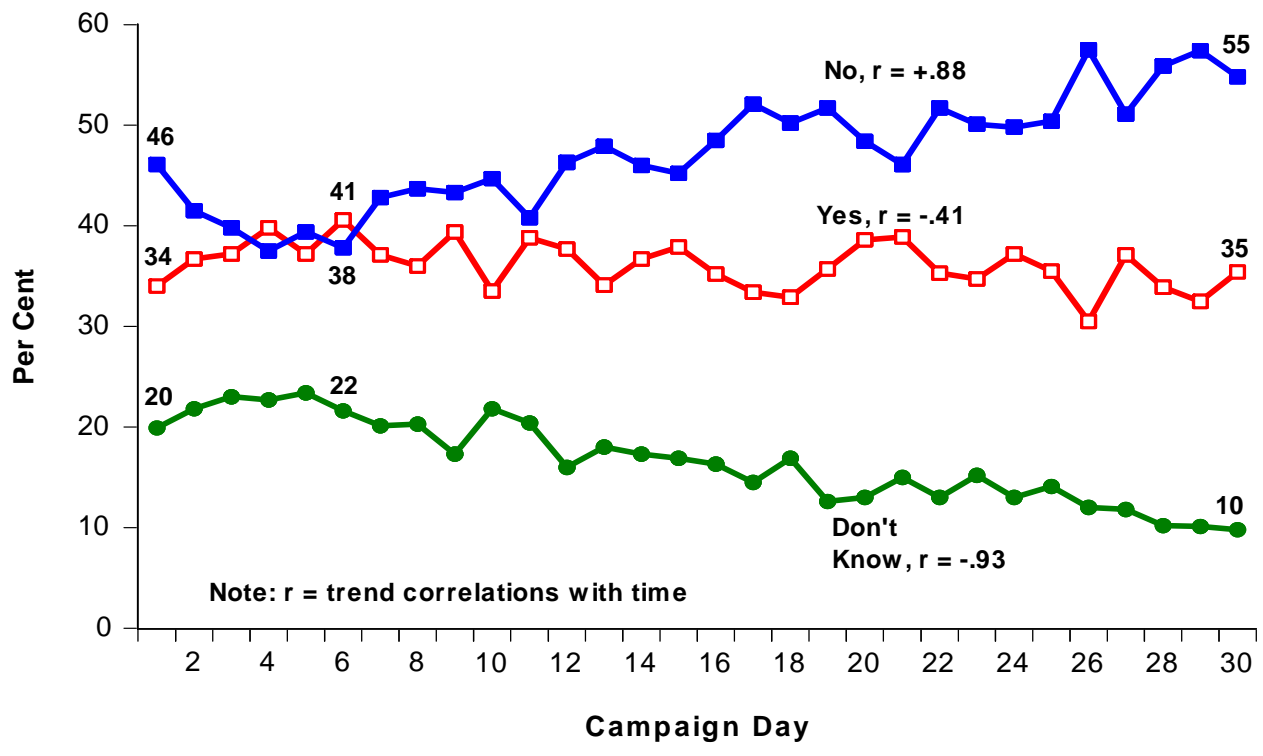

Source: Figure 1A: BES Monthly Continuous Monitoring Surveys and published YouGov polls asking actual referendum question; Figure 1B: daily random samples from the prereferendum wave of the BES AV Referendum survey. 
Figure 2. Yes Voting in the AV Referendum by Level of Political Knowledge

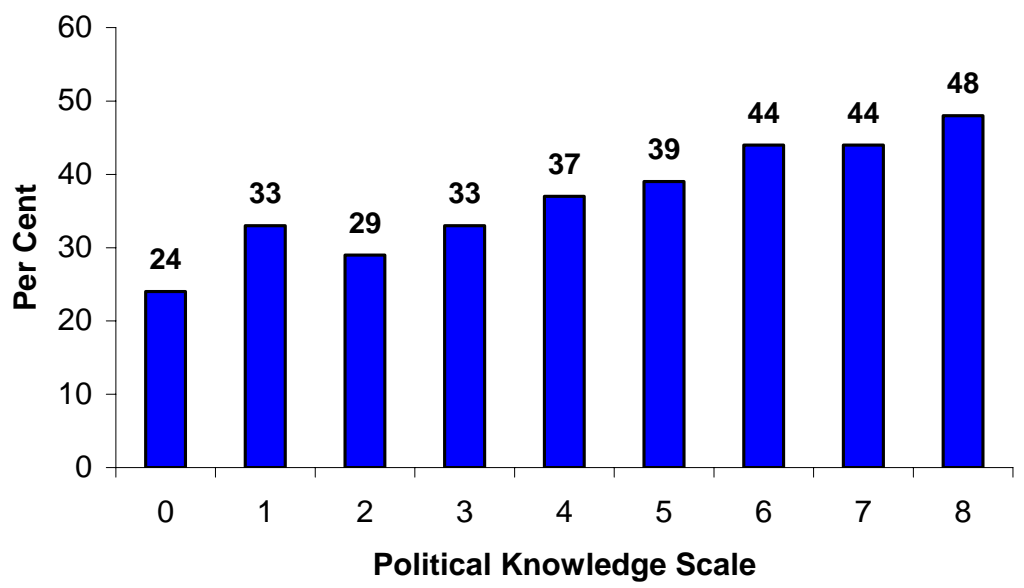


Figure 3. Percentages Voting Yes in AV Referendum by Party Leader Images

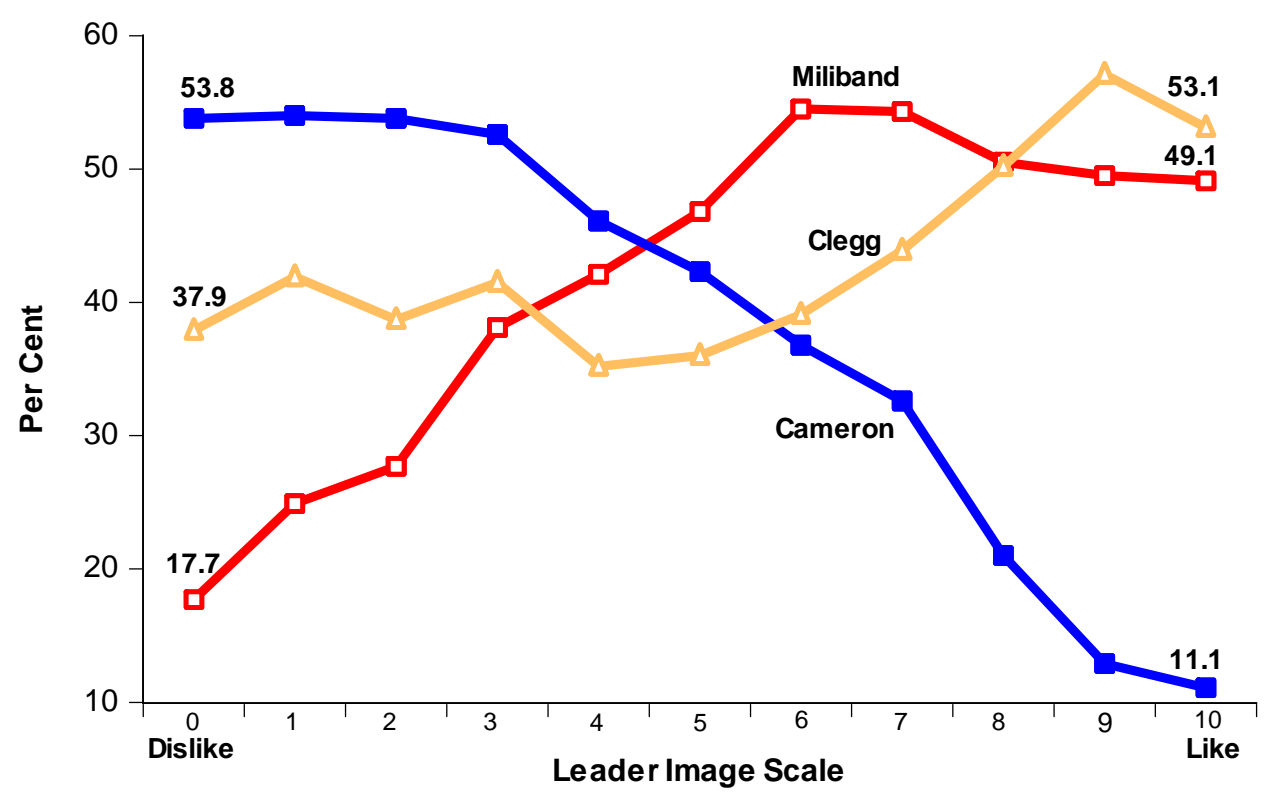


Figure 4. Changes in the Probability of Voting Yes Associated With Changes in Significant Predictor Variables

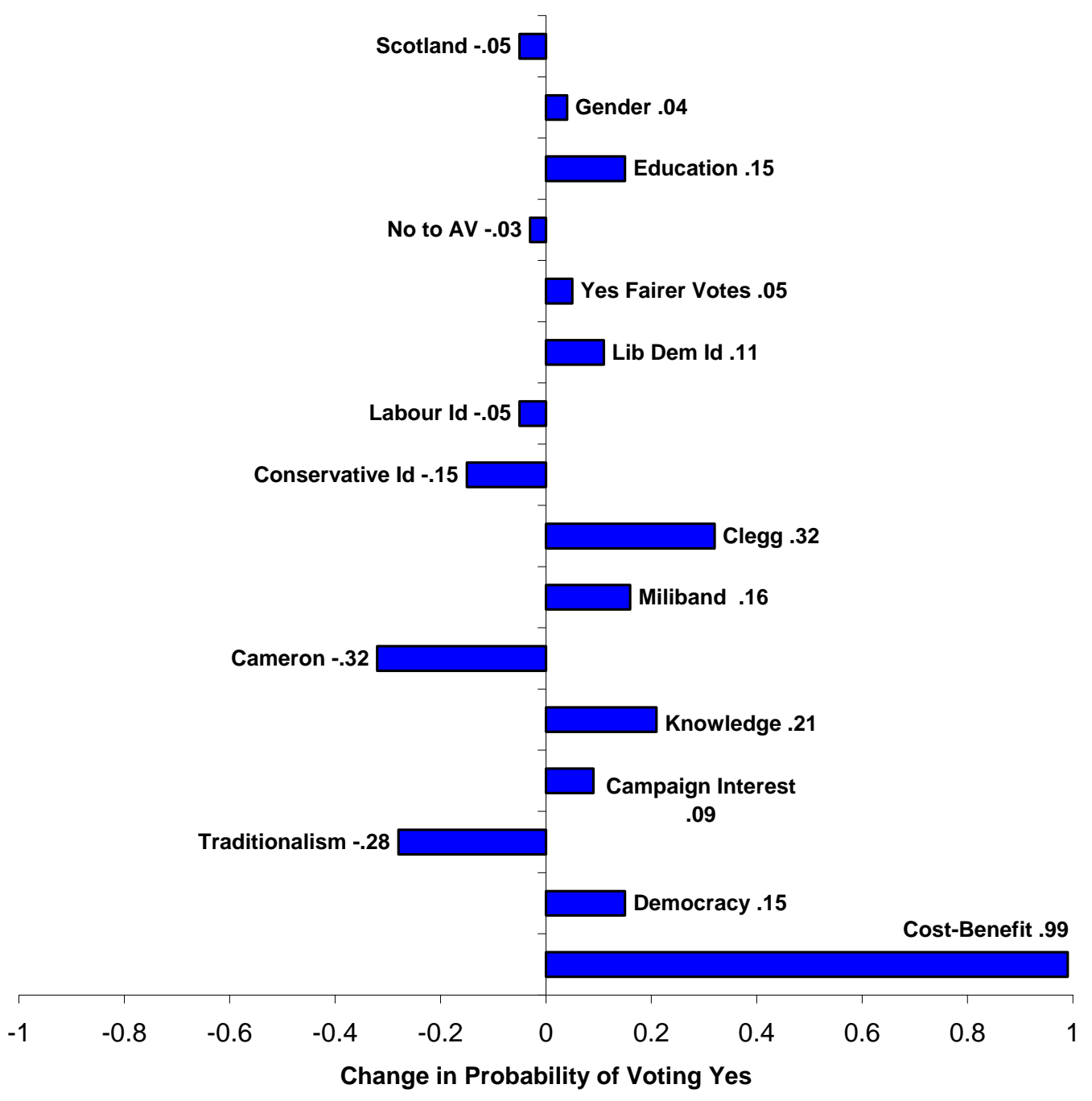


Figure 5. Reactions to the Yes and No Campaigns

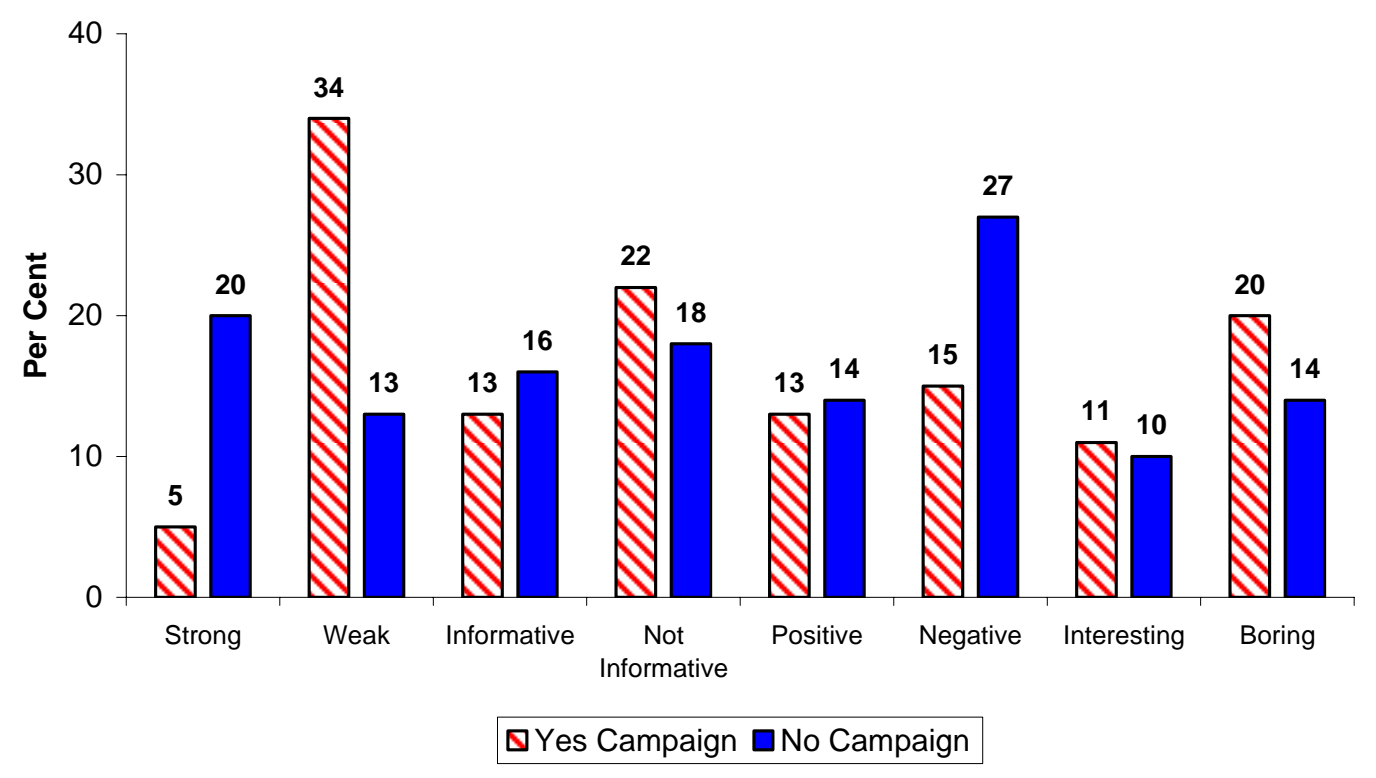

Source: BES AV Referendum post-referendum survey. 
Table 1. Attitudes the Alternative Vote and First-Past-The-Post Electoral Systems (Horizontal Percentages)

\begin{tabular}{|c|c|c|c|c|c|}
\hline Statement & $\begin{array}{l}\text { Strongly } \\
\text { Agree }\end{array}$ & Agree & Neither & Disagree & $\begin{array}{l}\text { Strongly } \\
\text { Disagree }\end{array}$ \\
\hline The AV system is fairer & 9 & 32 & 20 & 22 & 18 \\
\hline $\begin{array}{l}\text { AV gives too much influence to small } \\
\text { parties }\end{array}$ & 13 & 28 & 25 & 26 & 9 \\
\hline $\begin{array}{l}\text { Outcomes under AV more accurately } \\
\text { reflect opinions }\end{array}$ & 10 & 31 & 19 & 23 & 17 \\
\hline AV makes MPs work harder & 10 & 38 & 25 & 17 & 11 \\
\hline FPTP is part of the British tradition & 20 & 22 & 20 & 21 & 17 \\
\hline $\begin{array}{l}\text { FPTP allows voters to attribute } \\
\text { responsibility to parties }\end{array}$ & 15 & 41 & 24 & 16 & 5 \\
\hline AV is hard to understand & 7 & 30 & 23 & 28 & 13 \\
\hline
\end{tabular}




\section{Table 2. Attitudes Towards Constitutional Change (Horizontal Percentages)}

\begin{tabular}{|c|c|c|c|c|c|}
\hline Statement & $\begin{array}{l}\text { Strongly } \\
\text { Agree }\end{array}$ & Agree & Neither & Disagree & $\begin{array}{l}\text { Strongly } \\
\text { Disagree }\end{array}$ \\
\hline House of Lords should be elected & 24 & 37 & 19 & 14 & 6 \\
\hline $\begin{array}{l}\text { House of Commons should be } \\
\text { reduced to } 600 \mathrm{MPs}\end{array}$ & 30 & 40 & 18 & 8 & 3 \\
\hline $\begin{array}{l}\text { Local Government should have } \\
\text { more authority }\end{array}$ & 11 & 47 & 28 & 13 & 3 \\
\hline The Monarchy should be abolished & 9 & 8 & 13 & 23 & 48 \\
\hline $\begin{array}{l}\text { The Church of England should } \\
\text { keep its status as a state institution }\end{array}$ & 26 & 32 & 24 & 8 & 9 \\
\hline $\begin{array}{l}\text { The UK should use referendums to } \\
\text { decide important issues }\end{array}$ & 25 & 42 & 16 & 13 & 4 \\
\hline
\end{tabular}


Table 3. Binomial Logit Analysis of Yes Voting in AV Referendum

\begin{tabular}{l|ll}
\multicolumn{1}{c}{$\boldsymbol{B}$} & s.e. \\
\hline Cost-Benefit Scale & $2.43^{* * *}$ & 0.05 \\
Democracy Scale & $0.11^{* * *}$ & 0.03 \\
Traditionalism Scale & $-0.25^{* * *}$ & 0.03 \\
Interest in Referendum & $0.16^{* * *}$ & 0.03 \\
Political Knowledge & $0.14^{* * *}$ & 0.02 \\
Attention to Politics & 0.01 & 0.02 \\
Media Consumption of AV News & -0.00 & 0.02 \\
Cameron Image & $-0.17^{* * *}$ & 0.02 \\
Miliband Image & $0.08^{* * *}$ & 0.01 \\
Clegg Image & $0.15^{* * *}$ & 0.02 \\
Labour Identification & $-0.22^{* *}$ & 0.09 \\
Conservative Identification & $-0.81^{* * *}$ & 0.10 \\
Liberal Democrat Identification & $0.37^{* * *}$ & 0.12 \\
Other Party Identification & -0.08 & 0.11 \\
Yes to Fairer Votes Campaign & $0.25^{* *}$ & 0.09 \\
No to Av Campaign & $-0.17^{*}$ & 0.08 \\
Gender (Male) & $0.21^{* * *}$ & 0.06 \\
Age & 0.001 & 0.002 \\
Annual Family Income & 0.01 & 0.01 \\
Education & $0.15^{* * *}$ & 0.02 \\
Scotland & $-0.22^{* *}$ & 0.09 \\
Wales & -0.19 & 0.13 \\
Constant & $-2.86^{* * *}$ & 0.22 \\
McKelvey R & .75 & \\
Percentage Correctly Classified & 87.9 & \\
Lambda & .70 & \\
Log Likelihood & -4111.80 & \\
N & 15,137 & \\
$*$ & p p .05; ** - p $\leq .01 ; * * * ~ p \leq .001 ; 00-$ tailed tests for Scotland and Wales, one-tailed \\
tests for other predictors. & & \\
\hline
\end{tabular}




\section{References}

Ansolabehere, Stephen and Brian F. Schaffner. 2011. "Re-Examining the Validity of Different Survey Modes for Measuring Public Opinion in the U.S.: Findings From a 2010 Multi-Mode Comparison." Paper presented at the AAPOR Annual Conference, Phoenix AZ., May 12-15, 2011.

Blais, Andre, Elisabeth Gidengil, Neil Nevitte and Richard Johnston. 1996. The Challenge of Direct Democracy: The 1992 Canadian Referendum. Montreal: McGill-Queen's University Press.

Benoit, Kenneth. 2004. 'Models of Electoral System Change'. Electoral Studies 23:363-89.

Bogdanor, Vernon. 2011. The Coalition and the Constitution. Oxford: Hart Publishing.

Borooah, Vani K. 2002. Logit and Probit: Ordered and Multinomial Models. London: Sage.

Bowler, Shaun and Todd Donovan. 1998. Demanding Choices: Opinion, Voting and Direct Democracy. Ann Arbor: University of Michigan Press.

Boix, Carlos. 1999. 'Setting the Rules of the Game: The Choice of Electoral Systems in Advanced Democracies’. American Political Science Review. 93: 609-624.

Butler, David and Austin Ranney, eds.. 1994. Referendums Around the World: The Growing Use of Direct Democracy . London: Macmillan.

Clarke, Harold D. and Allan Kornberg. 1994. 'The Politics and Economics of Constitutional Choice: Voting in Canada’s 1992 National Referendum'. Journal of Politics 56: 940-62.

Clarke, Harold D, Allan Kornberg and Marianne Stewart. 2004. 'Referendum Voting as Political Choice: The Case of Quebec'. British Journal of Political Science, 34: 345-355.

Clarke, Harold D., David Sanders, Marianne C. Stewart and Paul Whiteley. 2004. Political Choice in Britain. Oxford: Oxford University Press.

Clarke, Harold D., David Sanders, Marianne C. Stewart and Paul Whiteley, eds. 2008. 'Internet Surveys and National Election Studies'. Journal of Elections, Public Opinion and Parties, 17: passim.

Clarke, Harold D. David Sanders, Marianne C. Stewart and Paul Whiteley. 2009. Performance Politics and the British Voter. Cambridge: Cambridge University Press.

Conlisk, John. 1996. "Why Bounded Rationality?" Journal of Economic Literature 34: 669700.

Conservative Party. 2010. Invitation to Join the Government of Britain: Conservative Party Manifesto, 2010. London: Conservative Party.

Dalton, Russell J. 2008. Citizen Politics: Public Opinion and Political Parties in Advanced Industrial Societies. 5th edition. Washington, D.C.: CQ Press. 
de Vrees, Claes H., ed. 2007. The Dynamics of Referendum Campaigns. London: Palgrave Macmillan.

Downs, Anthony, 1957. An Economic Theory of Democracy. New York: Harper and Row.

Electoral Commission. 2011. See http://ukreferendumresults.aboutmyvote.co.uk/default.aspx. accessed July 10th, 2011.

Farrell, David and Rüdiger Schmitt-Beck, eds.. 2002. Do Political Campaigns Matter?

Campaign Effects in Elections and Referendums. London: Routledge.

Green, Donald P. And Alan S. Gerber. 2004. Get Out the Vote! Washington D.C: The Brookings Institution.

Green, Donald P. and Ian Shapiro. 1996. Pathologies of Rational Choice Theory: A Critique of Applications in Political Science. New Haven: Yale University Press.

Gigerenzer. Gerd. 2008. Rationality for Mortals. Oxford: Oxford University Press.

Kahneman, Daniel, Paul Slovic and Amos Tversky, eds. 1982. Judgment under Uncertainty: Heuristics and Biases. Cambridge: Cambridge University Press.

Keeney, Ralph L and Howard Raiffa. 1993. Decisions with Multiple Objectives : Preferences and Value Tradeoffs. Cambridge: Cambridge University Press.

Kennedy, Peter. 2003. A Guide to Econometrics. Oxford: Blackwell.

Kuklinski, James H. and Paul J. Quirk. 2000. 'Reconsidering the Rational Public: Cognition, Heuristics, and Mass Opinion'. In Arthur Lupia, Mathew McCubbins and Samuel Popkin, eds. Elements of Reason. Cambridge: Cambridge University Press.

Labour Party, 2010. The Labour Party Manifesto: A Future Fair for All. London: Labour Party.

Liberal Democrats, 2010. Liberal Democrat Manifesto, 2010. London: Liberal Democrats.

LeDuc, Lawrence. 2003. The Politics of Direct Democracy: Referendums in Global Perspective. Toronto: Broadview Press.

LeDuc, Lawrence. 2005. 'Saving the Pound or Voting for Europe?: Expectations for Referendums on the Constitution and the Euro'. Journal of Elections, Parties and Public Opinion 15: 169-196.

Lupia, Arthur, 1994. "Shortcuts Versus Encyclopaedias: Voting in California Insurance Reform Elections. American Political Science Review 88: 63-76.

Lupia, Arthur and Mathew D. McCubbins. 1998. The Democratic Dilemma: Can Citizens Learn What They Need to Know. Cambridge: Cambridge University Press. 
Marcussen, Martin and Mette Zølner. 2001. 'The Danish EMU Referendum 2000'. Government and Opposition 36: 379-401.

Nadeau, Richard, Pierre Martin and Andre Blais. 1999. 'Attitude Towards Risk-Taking and Individual Choice in the Quebec Referendum on Sovereignty'. British Journal of Political Science, 29: 523-539.

Norris, Pippa. 2000. A Virtuous Circle: Political Communication in Postindustrial Societies. Cambridge: Cambridge University Press.

Norton, Philip. 2011. 'The Politics of Coalition'.In Nicholas Allen and John Bartle, eds., Britain at the Polls 2010. London: Sage.

Pattie, Charles. A. Edward A. Fieldhouse and Ron J. Johnston. 1995. 'Winning the Local Vote: The Effectiveness of Constituency Campaign Spending in Great Britain 1983-1992'. American Political Science Review, 89, 4: 969-83.

Popkin, Samuel. L. 1991. The Reasoning Voter: Communication and Persuasion in Presidential Campaigns. Chicago: University of Chicago Press.

Seyd, Patrick and Paul Whiteley. 1992. Labour's Grassroots: The Politics of Party Membership. Oxford: Oxford University Press.

Sanders, David, Harold D. Clarke, Marianne C. Stewart and Paul Whiteley. 2007. "Does Mode Matter for Modeling Political Choice? Evidence From the 2005 British Election Study." Political Analysis 15: 257-85.

Sniderman, Paul, Richard Brody and Philip E. Tetlock. 1991. Reasoning and Choice: Explorations in Political Psychology. Cambridge: Cambridge University Press.

Thaler, Richard. 1994. Quasi-Rational Economics. New York: Russell Sage Foundation.

Tomz, Michael, Jason Wittenberg and Gary King. 1999. "Clarify: Software for Interpreting and Presenting Statistical Results." Harvard University: Department of Government.

Vowles, Jack 1995. 'The Politics of Electoral Reform in New Zealand'. International Political Science Review 16: 95-115.

Whiteley, Paul. 1995. 'Rational Choice and Political Participation - Evaluating the Debate', Political Research Quarterly, 48: 211-234.

Whiteley, Paul. 2011. Political Participation in Britain: The Decline and Revival of Civic Culture. Oxford: Palgrave-Macmillan (forthcoming). 


\section{Endnotes}

${ }^{1}$ See http://bes2009-10.org. The authors wish to thank BPIX and the McDougall Trust for financial support that helped to make the referendum study possible. We also thank Joe Twyman, Study Director at YouGov, for his generous assistance in facilitating the project.

${ }^{2}$ See http://bpix.co.uk/

${ }^{3}$ The details of the political knowledge scale are discussed below.

${ }^{4}$ It noteworthy that in the 1975 referendum on continued UK membership in the European Community, the yes campaign held the status quo advantage since Britain had already joined the EC. The division of the vote was: 67.2 per cent yes and 32.8 per cent no. This level of endorsement of the status quo was virtually identical to that in the $2011 \mathrm{AV}$ referendum.

${ }^{5}$ Gigerenzer illustrates this point with an amusing story. A decision theorist from Columbia University was struggling whether to accept a job offer from another university. His colleague advised him to maximise his utility, something which he regularly wrote about in his research. The decision theorist responded: 'Come on, this is serious' (2008: 20).

${ }^{6}$ On the efficacy of high quality internet surveys for modelling political behaviour in Britain, see Sanders et al. (2007). See also Clarke et al. (2008). Similar findings for the U.S. are presented in a recent study by Ansolabehere and Schaffner (2011).

7 To measure opinion and vote intention dynamics in the run-up to the referendum, random samples were surveyed every day between April 5th and May 4th. The average size of these daily samples was $\mathrm{N}=732$.

${ }^{8}$ If predictor variables are measured well before a response variable, then it is unlikely that the latter is influencing the former (Kennedy, 2003: 301-315).

${ }^{9}$ These items were included in the second wave of the survey for space reasons.

${ }^{10}$ The statements in the tables are summaries. Actual question wording may be obtained from the survey questionnaires which may be downloaded from the BES website cited in note 2. The website also has a measurement appendix which discusses details of the construction of all the variables used in the analyses in this paper. The survey data are available on the website for replication purposes and secondary analyses by BES user communities.

11 The democracy and traditionalism factors explain 26.6 per cent and 25.1 per cent of the item variance, respectively.

${ }^{12}$ England is reference category.

${ }^{13}$ The simulations were performed using the Clarify programme available from Gary King's website at Harvard University (http://gking.harvard.edu). See Tomz, Wittenberg and King (2003).

${ }^{14}$ An amusing example is: 'Is Your Cat Confused About the Referendum on the Alternative Vote on 5th May'. See www.youtube.com/watch?v=HiHuiDD_oTk 
${ }^{15}$ Illustrative are the heated exchanges between Baroness Warsi and Chris Huhne concerning campaign financing and whether AV or FPTP would do the most to facilitate the fortunes of extreme parties such as the BNP. 